\title{
Aligning Small and Medium Enterprises for Competitiveness in Nigeria: The Role of Strategic Alliance
}

\author{
Onyeaghala Obioma $\mathrm{H}^{*}$ \\ Department of Business Administration, Federal University Wukari, Taraba State, Nigeria
}

\begin{abstract}
Businesses all over the world face competition and competitors have a major bearing on business performance. This study seeks to ascertain the role strategic alliance play in making small and medium enterprises achieve competitiveness. The study which employed the survey design covered six zones of Nigeria. The target population was all small and medium enterprises owners and their workers operating in the zones. These businesses are seen clustering in the major commercial cities of each zone and for each zone; three commercial cities were judgementally selected. Since their population was known and it was not possible to study the entire business that fall into this category, the sample size was determined using Taro Yamane formula. The instrument for data collection was the questionnaire, structured in a 5 point likert type scale. Reliability of the instrument was established. The questionnaire was administered to the respondents. Presentation and analysis of the data was carried out using frequency tables and simple percentages. The Pearson Product Moment Correlation was used for testing the formulated hypotheses aided by the Statistical Package for Social Sciences (SPSS) version 20.0. Findings show that: Combination of financial, material and human resources make small and medium enterprises develop competitive edge. Distribution of risk and reward makes small and medium enterprises build capacity to compete. This is to say; formation of alliance makes small and medium enterprises develop competitive ability. It is recommended that small and medium enterprises should form alliance in order to pool together financial, material and human resources with the sole aim of developing strong competitive ability which every business needs today for survival. As well, they need to distribute their risk in form of diversification across different industries and/or product lines, guide the alliance organization; watch their strategy implementation and culture of their allies.
\end{abstract}

Keywords: Strategic alliance; Contractual alliance; Mutual service consortia; Value-chain partnerships; Imitability; Woo and win

\section{Introduction}

Global competitive landscape is increasing day by day from the cradle of civilization to the jet age and businesses need to survive by evolving strategy options to improve their productivity and market share. As noted by Kaplan and Norton [1] creating shareholder value is the outcome that every strategy seeks to accomplish.

Every business needs to adopt strategies differently from others as its indicator of success by establishing linkages or relationship with some other businesses. One of the relationships that can make them pool resources together is called alliance. Alliance is a close relationship of businesses, sharing similar characteristics towards achieving common purposes. It is an agreement between business, usually motivated by cost reduction and improved service for the customer.

Strategic alliance is formed by developing a relation between two or more independent firms that agree to share resources to achieve some common objectives. Because of global competition and the constantly growing demand for new technologies, strategic alliances are becoming popular and important as its goal is to support the firm's competitiveness [2].

Small and medium enterprises are manufacturing, processing or service enterprises, that create independence, self-reliance, expectation of income and so forth for owners. They play critical role in economic development of nations. They are the hub and vitality for economic development of any society. Small and medium enterprises metamorphose to large scale businesses. Ade [3] noted that almost all the multinational giant corporations were small enterprises, growing as their industry grew.

As competition intensifies, this class of business is expected to put in place strategies to enable them struggle for the right of market share and gain competitive advantage over their rivals. In addition, they are expected to develop relationships with one another by pooling resources together. No doubt, a company can achieve high market share by pooling resources together with another firm; a fit that would be difficult to achieve alone. It is reasoned that if small and medium enterprises pool resources together, they will develop competitive advantage and necessary capacity to woo and win customers, and operate successfully.

\section{Problem Presentation}

Many people link alliance with corporations and large-scale businesses, they forget that every business needs one form of association or another to survive. According to Business alliance on small scale business [4-6] cited by Ade [3] and others reinforced the above statement saying that empirical research on business alliance had focused attention on larger concerns. This means that small and medium enterprises that have made immense contribution to economic development of nations, seems not to be receiving encouraging research attention.

Government at all levels through fiscal incentives, grants, bilateral and multilateral agencies as well as specialized institutions support and aids small and medium enterprises all geared towards making them vibrant [7]. The academics have theorized and proffered various cure

${ }^{*}$ Corresponding author: Onyeaghala Obioma $\mathrm{H}$, Department of Business Administration, Federal University Wukari, Taraba State, Nigeria, Tel: +2348035772477, E-mail: onyexinvltd@yahoo.com

Received April 28, 2017; Accepted June 21, 2017; Published June 24, 2017

Citation: Obioma O (2017) Aligning Small and Medium Enterprises for Competitiveness in Nigeria: The Role of Strategic Alliance. Review Pub Administration Manag 5: 215. doi:10.4172/2315-7844.1000215

Copyright: (c) 2017 Obioma O. This is an open-access article distributed under the terms of the Creative Commons Attribution License, which permits unrestricted use, distribution, and reproduction in any medium, provided the original author and source are credited. 
yet, these efforts have not done the expected magic to rescue most of them from dismal performance. It is reasoned that many small and medium enterprises in Nigeria have failed to develop competitive strategies which may have occasioned their lack of necessary capacity to successfully operate.

It is obvious that small and medium enterprises do not have human and financial muscle to access new technology and markets. Again, political and financial risks may be high for them to bear alone. Close observation has shown that many of them choose to operate on their own, perhaps for ego reasons. They ignore working in collaboration with others to develop competitive advantage and capacity which will enable them to compete successfully.

Unfortunately, however, some owners of these businesses feel that profit sharing affects them adversely or that they may not have the capacity to diversify. But it is reasoned that, because of their nature and sensitivity to changes and challenges in their operating environments, including competition, small and medium enterprises need cooperative arrangement to build capacity to remain competitive more than other classes of business. Maybe, they do not understand that lack of necessary capacity to operate can make them lose out in the face of changes and challenges and this may have a multiplier effect. It is for the foregoing disturbing issues that this study was designed.

\section{Objectives of the Study}

This study seeks to ascertain if business alliance can serve as a competitive strategy for small and medium enterprises. Specifically, the study is geared towards achieving the following objectives:

1. To determine if combination of financial and material resources can make small and medium enterprises develop competitive ability.

2.To find out if combination of human resources can make small and medium enterprises develop competitive edge.

3. To ascertain if distribution of risk and reward enhances the capacity of small and medium enterprises to compete.

\section{Research Questions}

In response to the purpose of this study, the following research questions were designed.

1. Does combination of financial and material resources make small and medium enterprises develop competitive ability?

2. Does combination of human resources make small and medium enterprises develop competitive edge?

3. Does distribution of risk and reward enhance the capacity of small and medium enterprises to compete?

\section{Research Hypotheses}

$\mathrm{Ho}_{1}$ : Combination of financial and material resources does not make small and medium enterprises develop competitive ability

$\mathrm{Ho}_{2}$ : Combination of human resources does not make small and medium enterprises develop competitive edge

$\mathbf{H o}_{3}$ : Distribution of risk and reward does not enhance the capacity of small and medium enterprises to compete.

\section{Significance of the Study}

The study will provide numerous benefits to academics, business practitioners and the government. Some of the benefits are presented below.
- To academics it will add to the existing volume of knowledge and pave way for future researches.

- To business practitioners; especially small and medium enterprise owners, this study will enable them have a better understanding of the need to pool resources together.

- To the government; specifically, it will guide business policy makers on how to adjust/formulate policies that will encourage business to form alliance and achieve win-win collaboration. This is because viable business activities make a viable economy.

\section{Conceptual Framework}

\section{Concept of Strategic Business Alliance}

An alliance is a relationship among people, groups or states that have joined together for mutual benefit or to achieve some common purpose [2]. Similarly, strategic business alliance is an agreement between two or more companies offering similar product/services or operating in the same market, to pool resources together to carry on a business for their benefit. Zamir et al. [8] define strategic alliances as the comparatively continuing provisions, separate from institutional arrangement, linking associations to consume resources and plan structures of independent organizations towards shared achievement objectives.

Wheelen and Hunger [9] view business alliance as the cooperative arrangement between two or more independent business units that engage in business activities for mutual economic gain.

For Zamir et al. [8], an organization of firms that let independent firms to share various resources is known as strategic alliances. According to them, alliance creates enormous opportunities for success and growth, secures the business in market place, give business an additional competitive edge and capacity enhancement. Also provides the advantage of decreased dependency on supplier and make companies potentially more self-sufficient.

Business alliances are a form of cooperative partnerships. For example, a furniture manufacturing firm might create a strategic alliance with a timber logging firm to form a single firm that supplies with constant and reliable quality of the raw material and finished products. As well, a furniture exporting firm may have alliance with a furniture manufacturing firm for production and supply of high quality final product.

Alliance provides the recipe which serves as a framework for organizations to combine their resources (tangible and intangible) effectively.

\section{Types of Strategic Alliances}

There are two forms of strategic alliance, these are: Contractual and equity [8].

\section{Contractual alliance}

Contractual forms of strategic alliance are made when a formal structure of management is not needed. They are usually short-term contracts. Contractual forms include franchising, licensing, joint research and development, project outsourcing, contractual agreements and management contracts.

\section{Equity alliance}

Equity form of alliance deals with the involvement of shares which include spaying (operating on) for an equity share and an exchange of equity in existing entities. No new entity is made, in this case. 
Wheelen and Hunger [9] presented similar classification of alliance with Zamir et al. [8], but with few differences. Their classification ranges from mutual service consortia to joint ventures, and licensing arrangement to value chain partnerships, as explained below.

\section{Mutual service consortia/consortium}

It is a partnership of similar companies in similar industries that pool their resources to gain a benefit that is too expensive to develop alone such as access to advanced technology.

\section{Joint venture (Licensing arrangement)}

A joint venture is a cooperative business activity formed by two or more separate organizations for strategic purposes. This arrangement creates an independent business entity and allocates ownership, operational responsibilities, and financial risks and rewards to each member, while preserving their separate identity/autonomy. Joint venture is formed to pursue an opportunity that needs a capability from two or more companies or business units, such as the technology of one and the distribution of another. Joint ventures often occur because the companies involved do not want to or cannot legally merge permanently.

\section{Licensing arrangements}

A licensing arrangement is an arrangement in which the licensing firm grants rights to another firm in another country or market to produce and/sell a product. The licensee pays compensation to the licensor in return for technical expertise.

\section{Value-chain partnerships}

A value-chain partnership is a strong and close alliance in which one company or unit forms a long-term arrangement with a key supplier or distributor for mutual advantage.

\section{Stages of business alliance}

The three stages of business alliance identified by Schreiner et al. [10] are illustrated below (Figure 1):

\section{Schreiner et al. explained these factors further as:}

* In first stage of alliance, alliances are formed by scrutinizing and selecting a suitable and reliable strategic partner.

* In the second stage the alliances are set, designed, job description and ownership at each level is made.

* Third stage is the managing and post formation evaluation stage, which includes supervising the perceived worth of the alliance outcome.

\section{Advantages of business alliance}

Outlined below are some of the advantages of strategic business alliance over traditional relationships as postulated by Mowla [11].
Cost: Alliances find the sources of cost and extra charges and then they eliminate and divide them, which decrease the cost and increase the profits. In traditional methods, the costs are put on others.

Value: Alliances focus on the customer satisfaction and partners to give added value products and services to attract as many customers as possible. Whereas in traditional relationships costs are given more value by making use of low bids services which results in problems in products and process and leads towards failure.

Productivity: Alliances understand failures and have a scope of variability by partnering with permanent few suppliers. But in traditional relationships there is increased variability by contacting more suppliers to get cheap raw materials.

Information: In alliances open communications, sharing knowledge and transparency is encouraged throughout the supply chain. But traditional relationships see information as protected knowledge and use as a weapon in win-lose negotiations.

Resources: Alliance partners invest resources and appoint people, to make the process work and to improve it by jointly including people, time and money to ensure the alliance success. Whereas in traditional way of doing business they see people, money and time as resources to defend themselves.

Risks and rewards: In an alliance, all partners divide risks and rewards. In traditional or formal way, usually risks are given away and rewards are kept.

Giving credence to the work of Mowla [11], Wheelen and Hunger [9] report that business unites form strategic alliance for the following reasons:

1. To obtain or learn new capabilities, if the desired knowledge or capability is based on tacit knowledge or on new poorly-understood technology.

2. To obtain access to specific markets by forming value-chain alliances with local or foreign companies either as parts suppliers or as sub-contractors.

3. To reduce financial risk as alliance takes less financial resources than going into business alone. Alliance with suppliers is a means of outsourcing an expensive activity.

4. To reduce political risk: Forming alliance with local partners is a good way to overcome deficiencies in resource and capabilities when expanding into international markets.

5. Das and Teng [12] also state that strategic alliances are created to access critical resources that improve competitive position.

\section{Strategic Alliance Success Factors}

Wheelen and Hunger [9] identified some factors that help to achieve successful strategic alliance. They are:

\section{Stage One}

Scrutinizing and selecting a suitable and reliable strategic partner.
Stage Two

\begin{tabular}{|l|l|l|l|l}
$\begin{array}{l}\text { Setting, designing job } \\
\text { description and ownership } \\
\text { at each level. }\end{array}$ & $\longrightarrow \begin{array}{l}\text { Managing and post } \\
\text { formation evaluation. }\end{array}$ \\
\end{tabular}

Source: Author's conceptualization. 
- Having a clear strategic purpose and finding a sitting partner with compatible goals and contemporary capabilities.

- Integrating the alliance with each partner's strategy while ensuring that mutual value is created for all partners.

- Identifying likely partnering risks and dealing with them when the alliance is formed.

- Allocating tasks and responsibilities so that each partner can specialize in what it does best.

- Creating incentives for cooperation to minimize differences in corporate culture or organization fit.

- Minimizing conflicts among the partners by clarifying objective and avoiding direct competition in the market place.

- In an international alliance, ensuring that those managing it have comprehensive cross-cultural knowledge.

- Exchanging human resources to maintain communication and trust. Not allowing individual egos to dominate.

- Operating with long term time horizons, because, the expectation of future gains can minimize short term conflicts

- Developing multiple joint projects so that many failures are counterbalanced by successes.

- Agreeing on a monitoring process. Sharing information to build trust and keeping projects on target. Monitoring customer responses and service complaints.

- Being flexible in terms of willingness to renegotiate the relationship in terms of environmental changes and new opportunities.

- Agreeing on an exit strategy when the partners' objectives are achieved or the alliance is judged a failure.

\section{Reasons for Failure of Strategic Business Alliances}

Alliance might fail to achieve its goals and objectives if the strategies are not implemented correctly or a plan is not made according to the goals of the alliance and inter-organization relationship is not managed properly. According to Zamir et al. [8] alliances fail because of some of the reasons outlined below.

- When strategy implementation goes out of control of any of the organizations in the alliance then, the alliance starts moving towards failure.

- When one organization depends solely on the partners of other alliances for skills, it is a drawback for the organization that depends on others.

- When the concept of unequal gains prevails in alliance, partner getting less out of the alliance while other partners gain more can cause problems and disagreement which can lead to failure.

- Conflicts between the partners to decide the objectives and plans can cause a change in the viability and relation of a particular alliance.

- Differences in cultural values may lead to failure as culture clashes and different thinking can create a situation where parties in organizations disagree to some aspects of agreement.

- Different environment and rules prevailing in partner organizations within same nationality also cause failure of strategic alliances
- When strategic alliances are created, many job positions and their descriptions are changed to achieve the goal of alliance. There are role ambiguities and uncertainty about specific roles that may not bind organizations from fulfilling their obligations created in the alliance.

\section{Business Competitiveness}

Meredith and Shafer [13] define competitiveness as the long-term viability of a firm or organization, or in a short term context as the current success of a firm in the marketplace as measured by its market share or its profitability. It is the capability of a firm to achieve customer share or profitability in the marketplace.

The US President's Council on Industrial competitiveness [14], defined competitiveness of a nation as the degree to which it can, under free and fair market conditions, produce goods and services that meet the test of international markets while simultaneously maintaining and expanding the real incomes of its citizens. Gleaning idea from that definition, competitiveness of a firm can be viewed as the degree to which it can provide goods and services desired by customers while meeting expectations of the owners.

Marketing oriented companies not only monitor and seek to understand customers but also research competitors and their brands to understand their strengths, and weaknesses, strategies and response patterns [15]. An organization is said to have developed competitiveness, if it has necessary capacity or strength to survive in a competitive environment.

One other factor that can make an organization develop capacity to compete is focus. When an organization chooses to stress one or two key areas of strength; it is referred to as a focused organization. For example, IBM is noted for its customer service, General Electric for its technology and Procter and Gamble for its consumer marketing [13] In Nigeria, Associated Bus Company (ABC Transport) is known for the comfort and safety of its bus service. These afore mentioned firms have three major attributes directly related to focus. They are:

(i) Stressing one key business value, i.e., concentrating on one key factor at a time

(ii) Sticking to what they know best, i.e., by giving heavy attention to their strength and building on it always.

(iii) Complete view on the customer value creation strategies that managers, entrepreneurs, and leaders can implement to help distinguish themselves from competitors.

Meredith and Shafer [13] identified inherent and salient factors of competitive advantage as:

- Closer and faster matches to customers' needs because changeover time from one product or service to another is quicker.

- Ability to supply the needed items in the volumes required for the markets as they develop

- Faster design-to-market time to meet new customer needs

- Lower cost of changing product to meet needs

- Ability to offer a full line of products or services without the attendant cost of stocking large inventories

- Ability to meet market demands even if delays develop in production or distribution or distribution process.

In addition, having the right types of flexibility can offer major competitive advantages. 


\section{Developing Sustainable Competitiveness}

Wheelen and Hunger [9] stressed that for a firm to be able to use its resources, capabilities, and competencies to develop a competitive advantage does not mean it will be able to sustain it. He identified two characteristics that determine the sustainability of a firm's distinctive competency as: durability and imitability.

Durability is the rate at which a firm's underlying resources, capabilities, or core competencies (a collection of competencies that is wide spread within the organization and can make them do exceedingly well) depreciate or become obsolete.

Imitability is the rate at which a firm's underlying resources, capabilities, or core competencies can be duplicated by others. Wheelen and Hunger [9] maintains that a firm's distinctive competency gives it competitive advantage in the market place, competitors will do what they can to learn and imitate that set of skills and capabilities. Of course, this is the situation today with Japanese and Italian versus Chinese and Nigerian made goods.

Hamel et al. [16], called capabilities that are fundamental to an organization's strategy and performance "core competences". With core competencies, organizations are able to generate a competitive advantage over competing firms when they accumulate resources and capabilities that are valuable, rare, not substitutable, and imperfectly imitable.

\section{Theoretical Framework}

The resource based view theory formed the underpinning of this study. The resource based view attempts to explain that a firm's competitive advantage rests on its unique combination of resources, competences and capabilities. Proponents of the resource based view often stress that the competitive advantage generated by a single organization from capabilities and competences are housed within the firm. Hamel et al. [16] extended this constricted perception and showed that this view can easily be extended to the field of collaborations. They argue that organizations should collaborate in order to win.

Therefore, cooperation from the resource based view leads to the insight that resource pooling can be identified as motivator for strategic alliance formation.

\section{Review of Empirical Literature}

Ade [3] conducted a study on Strategic agility and competitive performance in the Nigerian telecommunication industry, using a fivepoint Likert scale based on 21-items derived from existing literature to measure and assess the location of the sampled telecommunication firms on different dimensions of strategic agility. Data on profit growth, sales revenue, financial strength, operating efficiency and performance stability were collected from the firms' records. Results from the analysis showed a significant relationship between strategic agility and competitive performance. It was found that strategic agility influences the competitive performance of telecommunication firms in Nigeria (with a coefficient of 3.419). It was also found that strategic agility has a significant impact on and is a good predictor of competitive performance.

A survey carried out [17] on "The problem of sustaining the growth of small and medium enterprises in a typical sub-Saharan Africa context in South-East Nigeria" showed that over $70 \%$ of small and medium enterprises in the study area (the industrial layout of the South-East of Nigeria where this business is predominant) die within five years of establishment. The study found that poor infrastructural facilities, leading to high operational costs are the major impediments to sustaining the growth and survival of small and medium enterprises. The study recommended that for small and medium scale enterprises to exist without a threat of failure, they should join together and fight competition for their best of interest.

The works of Blodgett [18] shows, that forming joint ventures is a convenient way for corporations to work together with-out losing their independence. Their findings show that $30 \%$ to $50 \%$ of international joint ventures include three or more partners. In addition, joint ventures are often meant to be temporary especially by some companies that may view them as a way to rectify a competitive weakness until they can achieve long-term dominance in the partnership.

Zamir et al. [8] concurred with the findings of Blodgett [18] stressing, that in a strategic alliance, each company maintains its autonomy while gaining a new opportunity. He reported that a strategic alliance could help a company develop a more effective process, expand into a new market or develop an advantage over a competitor, among other possibilities.

Meurling [19] made impactful contribution saying strategic alliance allows penetrating into new markets and to achieve business goals, and it also helps to take a trial of some companies before making agreement with them.

\section{Methodology}

This study which employed the survey design was carried out in six geographical zones of Nigeria: South-east, South-south, South-west, North-east, and North-central and North-west. The target population for this study was all small and medium enterprises owners and their workers operating in the listed zones. It covered the following businesses: welding/fabrication, motor vehicle mechanics, upholstery makers, bakery, table water, tailoring, printing press, barbing and hair dressing saloon, paint/varnishes and shoe making. The choice of these businesses was informed by the harsh competition they face. These businesses are seen clustering in the major commercial cities of each zone and for each zone; three commercial cities were judgementally selected.

Since it was not possible to study the entire business that fall into this category from each commercial city and for the fact that their population was known the sample size was determined using Taro Yamane formula and a sample size of 106 was obtained.

The instrument for data was collection was the questionnaire, structured in a 5 point likert type scale of Strongly Agree (SA), Agree (A), Undecided (U), Disagree (D) and Strongly Disagree (SD).

Reliability of the instrument was conducted using the split-half method and a correlation coefficient for the two groups was computed using the Spearman Correlation Coefficient and a reliability coefficient of 0.6123 was obtained thus the instrument was accepted for use.

The questionnaire was administered to the 106 respondents of selected business owners and staff by the researcher. For presentation and analysis of the data the researcher used frequency tables and simple percentages. The Pearson Product Moment Correlation was used for testing the hypotheses aided by the Statistical Package for Social Sciences (SPSS) version 20.0

\section{Decision Rule}

Accept null hypothesis if $\mathrm{p}$-value is greater than 0.05 and reject null hypothesis if $\mathrm{p}$-value is less than 0.05 . 


\section{Data presentation and analysis}

From Table 1, on whether combination of capital help small and medium enterprises develop competitive ability, 21 respondents representing 26\% strongly agreed, 43 respondents (54\%) agreed, 8 respondents $(10 \%)$ were indecisive, 3 respondents (4\%) disagreed while 5 respondents (6\%) strongly disagreed. To ascertain whether combinations of machinery help small and medium enterprises develop competitive ability, 12 respondents (15\%) strongly agreed, 29 respondents (36\%) agreed, 24 respondents (30\%) were indecisive, 8 respondents (10\%) disagreed while 7 respondents (9\%) strongly disagreed. Finally, on whether combination of sources of supply help small and medium enterprises develop competitive ability, 15 respondents (19\%) strongly agreed, 41 respondents (51\%) agreed, 3 respondents (4\%) were indecisive, 16 respondents (20\%) disagreed while 5 respondents (6\%) strongly disagreed.

From Table 2, on whether pulling together of Initiative help small and medium enterprises develop competitive edge, 26 respondents representing 33\% strongly agreed, 35 respondents (44\%) agreed, 7 respondents (9\%) were indecisive, 9 respondents (11\%) disagreed while 3 respondents (4\%) strongly disagreed. On whether pulling together of technical skill help small and medium enterprises develop competitive edge, 13 respondents (16\%) strongly agreed, 47 respondents $(58 \%)$ agreed, 14 respondents (18\%) disagreed while 6 respondents (8\%) strongly disagreed. Also, on whether pulling together of managerial skill help small and medium enterprises develop competitive edge, 32 respondents (40\%) strongly agreed, 28 respondents (34\%) agreed, 2 respondents (3\%) were indecisive, 16 respondents $(20 \%)$ disagreed while 2 respondents (3\%) strongly disagreed.

From Table 3, on whether spreading of portfolios help small and medium enterprises to reduce risk, 19 respondents representing $24 \%$ strongly agreed, 30 respondents (38\%) agreed, 11 respondents (13\%) were indecisive, 12 respondents (15\%) disagreed while 8 respondents (10\%) strongly disagreed. On whether profit sharing has no negative effect in small and medium enterprises that form alliance, 23 respondents (30\%) strongly agreed, 36 respondents (45\%) agreed, 4 respondents (5\%) were indecisive, 7 respondents (9\%) disagreed while
9 respondents (11\%) strongly disagreed. Also, on whether Licensing is a means of risk distribution in small and medium enterprises, 8 respondents (10\%) strongly agreed, 28 respondents (34\%) agreed, 15 respondents (19\%) were indecisive, 25 respondents (31\%) disagreed while 4 respondents (5\%) strongly disagreed.

\section{Test Results of Hypotheses}

The result of Correlation showed that $\mathrm{r}\left(0.716^{* *}\right), \mathrm{p}=0.001$. Since the $\mathrm{p}$-value is less than the table value at 0.05 (i.e., $0.001<0.05$ ), the null hypothesis is rejected and the alternative hypothesis is supported.

The result of Correlation gives $r\left(0.633^{* *}\right), p=0.001$. Since the p-value of 0.001 is less than the table value at 0.05 (i.e., $0.001<0.05$ ), the null hypothesis is rejected and the alternative is accepted.

The result of Correlation shows an output results of $\mathrm{r}\left(0.802^{* *}\right)$, $\mathrm{p}=0.001$. The $\mathrm{p}$-value of 0.001 is less than the table value at 0.05 (i.e., $0.001<0.05$ ). The null hypothesis is refuted and the alternative hypothesis is upheld.

\section{Discussion of Findings}

\section{Hypothesis one}

Hypothesis one was tested and the result of Correlation analysis shows the null hypothesis which says combination of financial and material resources does not make small and medium enterprises develop competitive ability is rejected and the alternative hypothesis is supported. This implies that formation of alliance makes small and medium enterprises achieve competitiveness. This finding is in line with the view of Ronald who said that organizations should organize their exchanges of finances and other activities with other organizations when the aim is the minimization of production and transaction costs. In addition, it concurs with the findings of Barney, which reports that organizations are able to generate a competitive advantage over competing firms when they accumulate resources and capabilities that are valuable, rare, not substitutable, and imperfectly imitable. This implies that the more organizations form alliance, the easier they will survive competition (Table 4).

\begin{tabular}{|c|c|c|c|c|c|c|c|}
\hline \multirow{2}{*}{$S / N$} & \multirow{2}{*}{ Statement } & \multicolumn{6}{|c|}{ Number of response and percentage (\%) } \\
\hline & & SA & A & $\mathbf{u}$ & D & SD & Total \\
\hline 1 & Does combination of capital help small and medium enterprises develop competitive ability? & $21(26)$ & $43(54)$ & $8(10)$ & $3(4)$ & $5(6)$ & $80(100)$ \\
\hline 2 & Do combinations of machinery help small and medium enterprises develop competitive ability? & $12(15)$ & $29(36)$ & $24(30)$ & $8(10)$ & $7(9)$ & $80(100)$ \\
\hline 3 & Does combination of sources of supply help small and medium enterprises develop competitive ability? & $15(19)$ & $41(51)$ & $3(4)$ & $16(20)$ & $5(6)$ & $80(100)$ \\
\hline 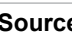 & Field Survey, 2016 & & & & & & \\
\hline
\end{tabular}

Table 1: Combination of financial and material resources in small and medium enterprises and development of competitive ability.

\begin{tabular}{|c|c|c|c|c|c|c|c|}
\hline \multirow{2}{*}{$\mathbf{S} / \mathbf{N}$} & \multirow{2}{*}{ Statement } & \multicolumn{6}{|c|}{ Number of response and percentage (\%) } \\
\hline & & SA & A & $U$ & D & SD & Total \\
\hline 1 & Does pulling together of initiative help small and medium enterprises develop competitive edge? & $26(33)$ & $35(44)$ & $7(9)$ & $9(11)$ & $3(4)$ & $80(100)$ \\
\hline 2 & Does pulling together of technical skill help small and medium enterprises develop competitive edge? & $13(16)$ & $47(58)$ & -- & $14(18)$ & $6(8)$ & $80(100)$ \\
\hline 3 & Does pulling together of managerial skill help small and medium enterprises develop competitive edge? & $32(40)$ & $28(34)$ & $2(3)$ & $16(20)$ & $2(3)$ & $80(100)$ \\
\hline
\end{tabular}

Table 2: Combination of human resources in small and medium enterprises and development of competitive edge.

\begin{tabular}{|c|c|c|c|c|c|c|c|}
\hline \multirow{2}{*}{$\mathbf{S} / \mathbf{N}$} & \multirow{2}{*}{ Statement } & \multicolumn{6}{|c|}{ Number of response and percentage (\%) } \\
\hline & & SA & A & $U$ & D & SD & Total \\
\hline 1 & Does spreading of portfolios help small and medium enterprises to reduce risk? & $19(24)$ & $30(38)$ & $11(13)$ & $12(15)$ & $8(10)$ & $80(100)$ \\
\hline 2 & Profit sharing has no negative effect in small and medium enterprises that form alliance. & $24(30)$ & $36(45)$ & $4(5)$ & $7(9)$ & $9(11)$ & $80(100)$ \\
\hline 3 & Is Licensing a means of risk distribution in small and medium enterprises? & $8(10)$ & $28(35)$ & $15(19)$ & $25(31)$ & $4(5)$ & $80(100)$ \\
\hline
\end{tabular}

Source: Field Survey, 2016

Table 3: Distribution of risk and reward, and capacity of small and medium enterprises to compete. 


\section{Hypothesis two}

The correlation analysis for hypothesis two gave a positive value, thus the null hypothesis which states that combination of human resources does not make small and medium enterprises develop competitive edge is rejected and the alternative which says combination of human resources (initiative, technical and managerial skill) make small and medium enterprises develop competitive edge is accepted. This finding aligns with that of Idemobi et al. [17] who found that for small and medium scale enterprises to exist without a threat of failure, they should join together and fight competition for their best of interest. Again, it agrees with the finding of Zamir et al. [8] which says that alliance creates enormous opportunities for success and growth, secures the business in market place; give business an additional competitive edge and capacity enhancement. It is equally in consonance with the outcome of Das and Teng [12] studies; that strategic alliances are created in order to access critical resources that improve competitive position. This is an indication that, the more organizations combine human and other resources, the greater they can cope and survive (Table 5).

\section{Hypothesis three}

The result obtained from data analysis support the rejection of null hypothesis which says distribution of risk and reward does not enhance the capacity of small and medium enterprises to compete. This means that the alternative hypothesis which says distribution of risk and reward enhances the capacity of small and medium enterprises to compete is accepted. This finding is in line with the views of respondents in this study (Table 3); majority of the respondents agreed that spreading of portfolios can help small and medium enterprises reduce risk. It is equally in agreement with the findings of Mowla [11], Wheelen and Hunger [9] who reported that business unites form strategic alliance to reduce financial and political risk (Tables 6-8).

\section{Conclusions}

Based on the findings of this study the researcher concludes that:

1. Formation of alliance makes small and medium enterprises develop necessary capacity to favourably compete with rivalries. Since strategic alliances create access for critical resources needed to develop competitive capacity. It shows that, the more organizations combine human and other resources, the greater they develop competitive capacity enhancement to fight competition for their best of interest.

2. Alliance creates enormous opportunities for success and growth for small and medium scale enterprises and secures the business in market place. It affords them the opportunity to join to distribute risk in form of diversification across different industries and/or product lines.

\section{Recommendations}

Based on the findings of this study, the following recommendations were made:

\begin{tabular}{|c|c|c|c|c|c|}
\hline \multicolumn{2}{|c|}{ Correlations } & $\begin{array}{c}\text { Achieving } \\
\text { competitiveness }\end{array}$ & $\begin{array}{l}\text { Combination of financial } \\
\text { and material resources }\end{array}$ & $\begin{array}{c}\text { Combination of human } \\
\text { resources }\end{array}$ & $\begin{array}{l}\text { Distribution of } \\
\text { risk and reward }\end{array}$ \\
\hline \multirow{3}{*}{ Achieving Competitiveness } & Pearson correlation & 1 & $0.716^{* *}$ & $0.633^{* *}$ & $0.802^{* *}$ \\
\hline & Sig. (2-tailed) & -- & 0.000 & 0.000 & 0.000 \\
\hline & $\mathrm{N}$ & 80 & 80 & 80 & 80 \\
\hline \multirow{3}{*}{$\begin{array}{l}\text { Combination of financial and } \\
\text { material resources }\end{array}$} & Pearson correlation & $0.716^{* *}$ & 1 & $0.721^{* *}$ & $0.764^{* *}$ \\
\hline & Sig. (2-tailed) & 0.000 & & 0.000 & .000 \\
\hline & $\mathrm{N}$ & 80 & 80 & 80 & 80 \\
\hline \multirow{3}{*}{ Combination of human resources } & Pearson correlation & $0.633^{\text {** }}$ & $0.697^{* *}$ & 1 & $0.686^{* *}$ \\
\hline & Sig. (2-tailed) & 0.000 & 0.000 & -- & .000 \\
\hline & $\mathrm{N}$ & 80 & 80 & 80 & 80 \\
\hline \multirow{3}{*}{ Distribution of risk and reward } & Pearson correlation & $0.802^{* *}$ & $0.758^{* *}$ & $0.658^{* *}$ & 1 \\
\hline & Sig. (2-tailed) & 0.000 & 0.000 & 0.000 & -- \\
\hline & $\mathrm{N}$ & 80 & 80 & 80 & 80 \\
\hline
\end{tabular}

Table 4: Correlation result.

\section{Correlations}

\begin{tabular}{|c|c|c|c|}
\hline \multicolumn{2}{|c|}{ Correlations } & Achieving competitiveness & Combination of financial and human resources \\
\hline \multirow{3}{*}{ Achieving competitiveness } & Pearson Correlation & 1 & $0.633^{* *}$ \\
\hline & Sig. (2-tailed) & -- & 0 \\
\hline & $\mathrm{N}$ & 80 & 80 \\
\hline \multirow{3}{*}{ Combination of human resources } & Pearson Correlation & $0.633^{* *}$ & 1 \\
\hline & Sig. (2-tailed) & 0 & -- \\
\hline & $\mathrm{N}$ & 80 & 80 \\
\hline
\end{tabular}

Source: SPSS, Version 20 result.

Table 5: Testing hypothesis two.

\begin{tabular}{|c|c|c|c|}
\hline \multicolumn{2}{|c|}{ Correlations } & Achieving Competitiveness & Distribution of risk and reward \\
\hline \multirow{3}{*}{ Achieving Competitiveness } & Pearson Correlation & 1 & $0.802^{* *}$ \\
\hline & Sig. (2-tailed) & -- & 0 \\
\hline & $\mathrm{N}$ & 80 & 80 \\
\hline \multirow{3}{*}{ Distribution of risk and reward } & Pearson Correlation & $0.802^{* *}$ & 1 \\
\hline & Sig. (2-tailed) & 0 & -- \\
\hline & $\mathrm{N}$ & 80 & 80 \\
\hline
\end{tabular}

Source: SPSS, Version 20 result.

Table 6: Testing hypothesis three. 
Citation: Obioma O (2017) Aligning Small and Medium Enterprises for Competitiveness in Nigeria: The Role of Strategic Alliance. Review Pub Administration Manag 5: 215. doi:10.4172/2315-7844.1000215

Page 8 of 8

\begin{tabular}{|c|c|c|c|c|c|}
\hline \multicolumn{2}{|c|}{ Correlations } & $\begin{array}{c}\text { Achieving } \\
\text { Competitiveness }\end{array}$ & $\begin{array}{l}\text { combination of financial } \\
\text { and material resources }\end{array}$ & $\begin{array}{l}\text { Combination } \\
\text { Human Resources }\end{array}$ & $\begin{array}{l}\text { Distribution of risk } \\
\text { and reward }\end{array}$ \\
\hline \multirow{3}{*}{ Achieving Competitiveness } & Pearson Correlation & 1 & $0.716^{* *}$ & $0.633^{* *}$ & $0.802^{* *}$ \\
\hline & Sig. (2-tailed) & -- & 0.000 & 0.000 & 0.000 \\
\hline & $\mathrm{N}$ & 80 & 80 & 80 & 80 \\
\hline \multirow{3}{*}{$\begin{array}{c}\text { combination of financial and } \\
\text { material resources }\end{array}$} & Pearson Correlation & $0.716^{*+}$ & 1 & $0.721^{* *}$ & $0.764^{* *}$ \\
\hline & Sig. (2-tailed) & 0.000 & -- & 0.000 & 0.000 \\
\hline & $\mathrm{N}$ & 80 & 80 & 80 & 80 \\
\hline \multirow{3}{*}{ Combination of Human Resources } & Pearson Correlation & $0.633^{*+}$ & $0.697^{* *}$ & 1 & $0.686^{* *}$ \\
\hline & Sig. (2-tailed) & 0.000 & 0.000 & -- & 0.000 \\
\hline & $\mathrm{N}$ & 80 & 80 & 80 & 80 \\
\hline \multirow{3}{*}{ Distribution of risk and reward } & Pearson Correlation & $0.802^{*+}$ & $0.758^{* *}$ & $0.658^{* *}$ & 1 \\
\hline & Sig. (2-tailed) & 0.000 & 0.000 & 0.000 & -- \\
\hline & $\mathrm{N}$ & 80 & 80 & 80 & 80 \\
\hline
\end{tabular}

Table 7: Testing hypothesis explaining combination of financial and material resources along with distribution of risk and reward.

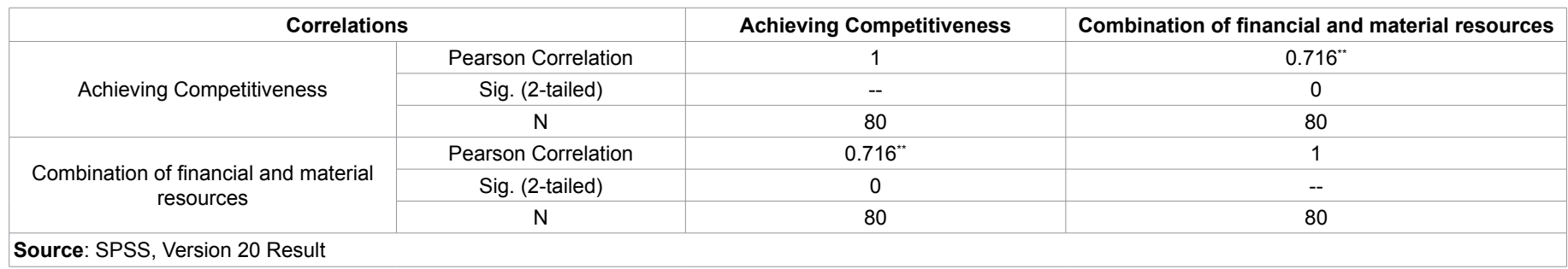

Table 8: Testing hypothesis explaining combination of financial and material resources.

1. For managers/owners of small and medium enterprises to effectively direct their businesses to survive competitions; they should form alliance with other businesses in order to collectively and efficiently handle competitive challenges. This will avail them the opportunity to constantly pool together financial, material and human resources with the sole aim of developing strong competitive ability which every business needs today for survival.

The findings of this study will increase the stock of literature in small and medium enterprises vis avis issues on alliance and inspire or open up more areas for further research.

\section{References}

1. Kaplan RS, Norton DP (2001) The strategy-focused organization, how balanced scorecard companies thrive in the new business environment. Harvard Business School Publishing Corporation, USA.

2. Vaidya S (2013) Strategic Alliances: A unification of the current literature. Republic of America: University of Texas-Pan America.

3. Ade O (2012) Business alliance on small scale business. Career Publishers, Owerri, Nigeria.

4. Cardinal P (2001) Business alliance on small scale business. Career Publishers, Owerri, Nigeria.

5. Haveman R (1993) Business alliance on small scale business Career Publishers, Owerri, Nigeria.

6. Harris O (2001) Business alliance on small scale Business. Career Publishers Owerri, Nigeria.

7. Murtala SS (2005) Entrepreneurship development policy: A renewed perspective for achieving economic development in Nigeria.
8. Zamir Z, Sahar A, Zafar F (2014) Strategic alliances: A comparative analysis of successful alliances in large and medium scale enterprises around the world. Educ Res Int J p: 3.

9. Wheelen TL, Hunger JD (2010) Strategic management and business policy: Achieving sustainability $\left(12^{\text {th }}\right.$ edn), Pearson, Prentice Hall, New Jersey.

10. Schreiner M, Kale P, Corsten D (2009) What really is alliance management capability and how does it impact Alliance outcomes and success? Strategic Manage J 30: 1395-419.

11. Mowla MM (2012) An overview of strategic alliance: Competitive advantages in alliance constellations. J Bus Manage Corp Affairs, Online Journal of Business and Marketing Management (OJBMM) 1: 1-10.

12. Das TK, Teng BS (1998) Between trust and control: Developing confidence in partner cooperation in Alliances. Acad Manage Rev 23: 491-512.

13. Meredith JR, Shafer SM (2015) Operations management ( $4^{\text {th }}$ edn), Singapore, John Wiely and Sons Pvt. Ltd.

14. The US President's Council on Industrial competitiveness (1985) Competitiveness of a Nation.

15. Jobber D (2007) Principles and practice of marketing ( $5^{\text {th }}$ edn), Mcgraw- Hill Education, UK

16. Hamel G, Doz Y, Prahalad CK (1989) Collaborate with your competitors and Win. Harv Bus Re, 67: 133-140.

17. Yoshino MY, Rangan S (1995) What is a strategic alliance - Strategic alliances: An entrepreneurial approach to Globalization, World of Alliances. Harvard Business School Publishing Corporation, USA

18. Blodgett LL (1992) Factors in the instability of International Joint Venture: An event history analysis. Strategic Management Journal 13: 475-481.

19. Meurling E (2001) Strategic alliances in the telecommunications sector. An EC Competition law assessment, Thesis, Lund University, Department of Law, Sweden. 